\title{
CHEMICAL COMPOSITION AND QUALITY OF SPINACH PLANT (SPINACH OLERACEA L.) AS AFFECTED BY MINERAL FERTILIZATION AND SOME RESIDUAL PLANT EXTRACTS. \\ El-Sirafy, Z. M. ${ }^{1}$; G. A. Baddour ${ }^{2}$ and Bosy F. Abas ${ }^{1}$ \\ 1- Soils Dept, Faculty of Agriculture, Mansoura University. \\ 2- Soil. Water and Environ. Res. Inst.; Agric. Res. Center. Giza. Cairo.
}

\section{ABSTRACT}

Two pot experiments were carried out under the green house of Faculty of Agriculture.; El-Mansoura University during the two successive winter seasons of 2006-2007 and 2007-2008 to study the substitution of some organic extracts which prepared from potato, tomato and fruit leaves instead of a part of mineral fertilizer to produce a safe yield of spinach plant. Twelve treatments were arranged in complete randomize block design with 3 replicates, which were the simple possible combination between four treatments of plant extracts $(0$, Potato extract, Tomato extract and fruit leaves extract) for foliar spraying and three treatments of $N, P$ and $K$ fertilizers $(0,50$ $\%$ and $100 \%$ ) of recommended doses as soil addition and their combination. The obtained results can be summarized as follow:

- Spraying of residual plant extracts either in a single form or in combination with mineral fertilization led to a positive effect on the growth and yield of spinach plants.

- Increasing the rate of N, P and K fertilization from 50 to $100 \%$ RD significantly increased the mean values of N, P and K contents in the leaves of spinach plant; such effect had no significant effect on the values of Fe $(\mathrm{mg} / 100 \mathrm{~g})$.

- The accumulation of nitrate and nitrite in spinach fresh leaves increased as the level of mineral fertilizers increased. Foliar spraying of residual plant extracts which contain micronutrients in the presence of mineral fertilizers resulted in pronounces decrease in the values of $\mathrm{NO}_{3}-\mathrm{N}$ and $\mathrm{NO}_{2}-\mathrm{N}$ in spinach plant.

- Foliar spraying of plant residual extracts as solely had no significant effect on the mean values of total oxalate, while such effect significantly increased the values of soluble oxalate as compared to the untreated plants. There is no significant difference between the average values of total oxalate in spinach plant due to an addition of $\mathrm{N}, \mathrm{P}$ and $\mathrm{K}$ fertilizers combined with spraying of residual plant extracts as compared to the same values obtained from the plants treated with $\mathrm{N}, \mathrm{P}$ and $\mathrm{K}$ fertilizers only.

- Under the same condition of this investigation it could be recommended that; soil addition of $\mathrm{N}+\mathrm{P}+\mathrm{K}$ fertilizers at the rate of $50 \%$ from the recommended doses for spinach plant coupled with foliar spraying of potato foliage residual extract is considered as the best treatment for producing a safe yield of spinach plant.

Keywords: residual plant extracts, mineral fertilizers, oxalate, nitrate, nitrite, spinach plant.

\section{INTRODUCTION}

Spinach (Spinach oleracea L.) is one of the major leafy vegetables, which is widely cultivated in Egypt. Spinach is a good source of vitamin $A, B_{1}$, $\mathrm{B}_{2}$ and $\mathrm{C}$, as well as minerals such as calcium, iron and magnesium (Kawazu 
et al., 2003). Nonetheless, its nutritive value in human diets is limited to a large extent because it is also rich in oxalate and nitrate.

Oxalates are common constituents of plants and are found in the majority of plant families. The amount of oxalates in plants ranges from a few percent of dry weight to up to $80 \%$ of the total weight of the plant (Franceschi and Loewus, 1995). Oxalate accumulates primarily as soluble oxalate salts such as potassium $(\mathrm{K})$, sodium $(\mathrm{Na})$ and insoluble oxalate such as calcium (Ca), iron (Fe) and magnesium (Mg) (Libert and Franceschi, 1987). High oxalate in diets can bind with some minerals to form insoluble oxalate salts which are hard to be absorbed by intestines and cause deficiencies of calcium, iron, magnesium and copper (Noonan and Savage, 1999 and Bohn et al., 2004) Intakes of oxalate-rich vegetables will increase the risk of kidney stones by inducing a significant increase in unitary oxalate extraction (Ogawa et al., 2000 and Lewandowski and Rodgers, 2004).

The harmful effects of nitrate are related not so much to its toxicity, when it low, but to the dangerous compounds that are synthesized in the organism. Indeed, the most serious danger comes from nitrite which is produced by nitrate reduction and which can lead to methamoglobinemia as from nitrosamines and nitrosamides by reacting with amines and amides, whose carcinogenic action is well known. (Gangolli et al., 1994). Other claims have been advanced against dietary nitrate such as; an increased risk of congenital malformation, a tendency towards enlargement of the thyroid gland, an early onset of hypertension and enhanced incidence of childhood diabetes (Herondel and Herondel, 2001).

The accumulation of oxalate and nitrate in the plants depends upon many environmental and biological factors, e.g. fertilizer application, light intensity, plant species and cultivars (Kawazu et al., 2003 and Proietti et al., 2004). Nitrogen nutrition is one of the most important factors affecting oxalate and nitrate content in spinach plant (Elia et al., 1998, Zhang et al., 2004 and Jaworska, 2005).So all world back to organic farming by using a new method to produce organic fertilizer from organic wastes such as plant residuals extracts to produce safe food and protection the environment from pollution (Abd El-Hamid et al., 2004).

Compost tea mean a liquid extract of compost that contains plant macro and micronutrients, plant growth regulators and beneficial microorganisms (Abd El-Hamied et al., 2004). This extract have been derived from plant materials (potato residual, tomato residual and fruit leaves residual) and animal manures (FYM) and produced by steeping finished compost in order to extract beneficial microorganisms and compounds into solution (Ingham, 2000 a).Compost tea can be applied directly to the plant as a foliar spray as affine mist on leaves of plants (Ingham, $2000 \mathrm{~b}$ ).

Compost tea induce a lot of benefits such as: Increase the biomass, species diversity of microbes and microbial inoculants via soil application to help build soil microbial population (Schmitz, 2002); increase the ability of soil to hold nutrients, retain water (Abd El-Hamid et al., 2004); reduce fertilizer use and leaching into ground water (Amer, 2005) and provide nutrients for foliar or spray application (Ryan et al., 2005). 
The present work aims to substitute some organic extracts instead of a part of mineral fertilizers for spinach plant.

\section{MATERIALS AND METHODS}

Two pot experiments were conducted under the green house of Fac. of Agric., Mansoura Univ. during two successive winter seasons of 2006-2007 and 2007-2008. This work aimed to substitute some organic extracts instead of a part of mineral fertilizers for spinach plant.

\section{Experimental Soil:}

The soil used was taken from the surface layer $(0-20 \mathrm{~cm})$ of clay soil from special farm located near El-Mansoura city; Dakahlia Government. Soil sample was air dried and analyzed to determine some physical and chemical properties as shown in Table 1.

Preparation of plant extracts: before sowing, compost from potato, tomato and fruit leaves was prepared before each season at the same location of the experiment. The residual foliage of potato and tomato plants were brought from a special farm near El-Mansoura city, while fruit leaves were taken from the citrus orchard; Faculty of Agriculture, Mansoura University. $10 \mathrm{~kg}$ was taken from each residual plant (Potato, tomato and fruit leaves). Plant material were chopped into segments of $2-5 \mathrm{~cm}$ and divided into three heaps. Each heap was mixed with $250 \mathrm{~g}$ ammonium sulphate , $60 \mathrm{~g}$ calcium superphosphate and $1000 \mathrm{~g}$ FYM (ripe) as an activation mixture according to Abo El-Fadl ( 1970 ) ; moisted to reach about $60 \%$ of its water holding capacity ; covered with plastic sheet and left to decay for 90 days. Throughout the decay; each heap was turned every 15 days and sprayed with water to keep its moisture around $60 \%$ of water holding capacity.

After 90 days; one kilogram of solid compost was put in plastic tanks and soaked into $5 \mathrm{~L}$. of tap water over 24 hours. Then, this mixture was stirred for 2 hours and strained by cheesecloth into other plastic tank. Chemical analysis of plant residuals extracts is shown in Table 2 
El-Sirafy, Z. M. et al.

9158 
Table (2): Chemical analysis of plant residuals extracts (aquies extract) in the two seasons:

\begin{tabular}{|c|c|c|c|c|c|c|c|}
\hline \multicolumn{2}{|c|}{ Extract } & \multicolumn{6}{c|}{$\mathbf{~ m g / \mathbf { L } ^ { - 1 }}$} \\
\cline { 3 - 8 } & $\mathbf{N}$ & $\mathbf{P}$ & $\mathbf{K}$ & $\mathbf{F e}$ & $\mathbf{Z n}$ & $\mathbf{M n}$ \\
\hline $\begin{array}{c}\text { Potato } \\
\text { extracts }\end{array}$ & $\mathbf{1}^{\text {st }}$ & 77 & 19.6 & 428 & 35.6 & 11.7 & 18.2 \\
\cline { 2 - 8 } & $\mathbf{2}^{\text {nd }}$ & 79 & 17.8 & 423 & 32.5 & 10.8 & 15.3 \\
\hline $\begin{array}{c}\text { Tomato } \\
\text { extracts }\end{array}$ & $\mathbf{1}^{\text {st }}$ & 67 & 14.2 & 395 & 29.8 & 9.3 & 14.5 \\
\cline { 2 - 8 } & $\mathbf{2}^{\text {nd }}$ & 71 & 14.9 & 412 & 27.3 & 9.7 & 10.9 \\
\hline $\begin{array}{c}\text { fruit leaves } \\
\text { extracts }\end{array}$ & $\mathbf{1}^{\text {st }}$ & 53 & 9.9 & 376 & 25.3 & 8.9 & 13.6 \\
\cline { 2 - 8 } & $\mathbf{2}^{\text {nd }}$ & 56 & 10.3 & 384 & 21.6 & 9.1 & 11.2 \\
\hline
\end{tabular}

Treatments: 12 treatments were arranged in randomized complete block design with three replicates which were the simple possible combination between three treatments of mineral fertilization as soil application and four treatments of plant extracts as foliar spraying. Thus, Treatments were arranged as follows:

1- Control treatment (without any addition).

2- Fruit leaves extract spraying.

3- Tomato foliage extracts spraying.

4- Potato foliage extracts spraying.

$5-50 \%$ of recommended dose (RD) [100 Kg ammonium sulphate, 75 $\mathrm{Kg}$ calcium super-phosphate and $50 \mathrm{Kg}$ potassium sulphate]. i.e $1.0 \mathrm{~g}, 0.75 \mathrm{~g}$ and $0.5 \mathrm{~g} /$ pot as ammonium sulphate, calcium super-phosphate and potassium sulphate respectively.

6- $50 \%$ of RD + fruit leave extract spraying.

$7-50 \%$ of $\mathrm{RD}+$ tomato foliage extract spraying.

8- $50 \%$ of $\mathrm{RD}+$ potato foliage extract spraying.

$9-100 \%$ of RD [200 Kg ammonium sulphate, $150 \mathrm{Kg}$ calcium superphosphate and $100 \mathrm{Kg}$ potassium sulphate]. i.e $2.0 \mathrm{~g}, 1.5 \mathrm{~g}$ and $1.0 \mathrm{~g} / \mathrm{pot}$ as ammonium sulphate, calcium super-phosphate and potassium sulphate respectively.

10- $100 \%$ of $R D+$ fruit leave extract spraying.

$11-100 \%$ of $R D+$ tomato foliage extract spraying.

$12-100 \%$ of $R D+$ potato foliage extract spraying.

Cultivation: 36 polyethylene pots; $20 \mathrm{~cm}$ in diameter and $30 \mathrm{~cm}$ height. Each pot was filled with $10 \mathrm{~kg}$ air dried soil. At 4 and 5 of December 2006 and 2007, respectively 20 seeds from spinach (Pacifice cv) was selected for uniformity in size and colour were sown. After 15 days from sowing plants were thinned to the most 6 uniform plants per pot.

Fertilization: Ammonium sulphate $(20.5 \% \mathrm{~N})$, calcium superphosphate $\left(15.5 \% \mathrm{P}_{2} \mathrm{O}_{5}\right)$ and potassium sulphate $\left(48 \% \mathrm{~K}_{2} \mathrm{O}\right)$ were used as a source of $\mathrm{N}, \mathrm{P}$ and $\mathrm{K}$, respectively. For the treatments of mineral fertilization three levels as a rate of recommended dose $(0,50 \%$ and $100 \%)$ from recommended doses of $\mathrm{N}, \mathrm{P}$ and $\mathrm{K}$ for spinach plant.

Each level of N, P and K fertilization was divided into two doses; one was added after 20 days from sowing and the other 20 days later. 
Foliar application of plant extracts at the rates of this study was conducted 3 times beginning after 20 days from sowing with 7 days interval at the rate of $100 \mathrm{ml} /$ pot.

Experimental procedures: At harvesting stage (60 days after sowing) plant growth parameters expressed as; Fresh weight (g/Plant), Dry weight ( $\mathrm{g} /$ Plant) and Fresh yield ( $\mathrm{g} /$ Pot). The oven dry plants of spinach plant was wet digested to determine $\mathrm{N}, \mathrm{P}, \mathrm{K}$ and $\mathrm{Fe}$ In addition nitrate, nitrite, total and soluble oxalate .

Method of analysis: Total nitrogen (\%), Organic matter and Available nitrogen and Potassium \% were determined according to Hesse (1971). Total phosphorus (\%), Total Potassium (\%) and Available phosphorus were estimated as described by Jackson (1967). Determination of total $\mathrm{Fe}, \mathrm{Mn}, \mathrm{Zn}$ and Available Fe were according to Chapman et al. (1961).Mechanical analysis and $\mathrm{CaCO}_{3}$ were determined as described by piper (1950). Total and soluble oxalate was determined according to the method described by Baker (1954). Nitrate and nitrite were measured by using a rapid method Singh (1988).

Statistical analysis: The statistical analysis of the collected data was done according to the method described by (Gomez and Gomez 1984) using LSD to compare the means of treatment values.

\section{RESULTS AND DISCUSSION}

\section{1- Fresh \& dry weight of spinach plant and fresh yield:}

Data presented at Table (3) illustrate the mean values of fresh and dray weight ( $\mathrm{g} / \mathrm{plant})$ as well as fresh yield ( $\mathrm{g} / \mathrm{pot}$ ) for spinach plant as affected by foliar spraying of residual plant extracts, soil addition of mineral fertilizers and their interaction during both seasons of 2006-2007 and 2007-2008.

Data reveal that; spraying of residual plant extracts as solely form significantly increased the mean values of all studied growth parameters as compared to the untreated plant. In this respect; foliar addition of residual foliage extract of potato $(P)$ was superior for increasing these parameters followed by tomato residual extracts $(T)$ and finally, fruit leaves extracts $(F)$. In the $1^{\text {st }}$ season, the mean values were $13.29,14.77,15.72 \& 16.29$ for fresh weight, $1.44,1.52,1.66$ \& 1.76 for dry weight and $76.02,84.23,89.23$ \& 91.78 for fresh yield $(\mathrm{g} / \mathrm{pot})$ for the treatment of $0, \mathrm{~F}, \mathrm{~T}$ and $\mathrm{P}$, respectively. The same trend was true during the $2^{\text {nd }}$ season of experiment.

Such data at Table (3) show that; the average values of all investigated growth parameters were significantly increased as the levels of $\mathrm{N}+\mathrm{P}+\mathrm{K}$ were increased. The rate of increases percent over the control treatment were accounted to be 28 and $36 \%$ for fresh weight, 30 and $69 \%$ for dry weight and 28 and $34 \%$ for the fresh yield in the $1^{\text {st }}$ season for the treatments of $50 \%$ and $100 \%$ from the RD of NPK, respectively. Such effect was happened in the $2^{\text {nd }}$ season. In this connection; increasing the rate of $\mathrm{N}+\mathrm{P}+\mathrm{K}$ fertilization from 50 to $100 \%$ of RD had no significant effect on the values of fresh yield $(\mathrm{g} / \mathrm{pot})$ during both seasons of the experimentation. 
As for the interaction effect between the treatments under study, data at Table (3) reveal that; at any rate of $\mathrm{N}+\mathrm{P}+\mathrm{K}$ fertilization combined with $\mathrm{F}$ or $\mathrm{T}$ or $\mathrm{P}$ foliar spraying significantly increased the mean values of fresh weight, dry weight and fresh yield than those realized for the plants received these rates of NPK solely.

The highest values $22.47,2.89 \& 126.06$ in the $1^{\text {st }}$ season and 23.64 , $2.97 \& 134.68$ in the $2^{\text {nd }}$ season for fresh and dry weight ( $\left.\mathrm{g} / \mathrm{plant}\right)$ and fresh yield (g/pot), respectively were realized for the plants treated with $\mathrm{N}+\mathrm{P}+\mathrm{K}$ at the rate of $100 \%$ from (RD) coupled with potato residual extract in foliar way.

It could be concluded that, spraying of residual plant extracts either in a single form or in combination with mineral fertilization led to a positive effect on the growth and yield of spinach plants. This can be attributed to the role played by these extracts for hastening the performance of nutrients availability in the presence of mineral fertilizer, beside high biological benefits of the used residual extracts.

These results were in accordance with these obtained by Maftoun et al., (2004), Tartoura et al., (2005), Lashin (2006), Rashwan (2006), Abd ElWahab et al., (2007) and El-Serafy et al., (2008) who concluded that; at any level of $\mathrm{N}, \mathrm{P}$ and $\mathrm{K}$ fertilization studied the foliar spraying of compost tea on the leaves of pea plants led to increase the mean values of growth parameters and yield of plant.

Table (3): Fresh \& dry weight of spinach plant and fresh yield as affected by mineral fertilization and some residual plant extracts.

\begin{tabular}{|c|c|c|c|c|c|c|}
\hline Seasons & \multicolumn{3}{|c|}{ 2006-2007 } & \multicolumn{3}{|c|}{ 2007-2008 } \\
\hline ient? & $\begin{array}{c}\text { Fresh } \\
\text { weight } \\
\text { g/plant }\end{array}$ & $\begin{array}{c}\text { Dry weight } \\
\text { g/plant }\end{array}$ & $\begin{array}{c}\text { Fresh yield } \\
\text { g/pot }\end{array}$ & $\begin{array}{c}\text { Fresh } \\
\text { weight } \\
\text { g/plant }\end{array}$ & $\begin{array}{c}\text { Dry weight } \\
\text { g/plant }\end{array}$ & $\begin{array}{c}\text { Fresh yield } \\
\text { g/pot }\end{array}$ \\
\hline Control & 13.29 & 1.44 & 76.02 & 14.13 & 1.47 & 79.76 \\
\hline $\mathbf{F}$ & 14.77 & 1.52 & 84.23 & 15.53 & 1.57 & 88.43 \\
\hline$T$ & 15.72 & 1.66 & 89.23 & 16.46 & 1.71 & 93.82 \\
\hline $\mathbf{P}$ & 16.29 & 1.76 & 91.78 & 17.15 & 1.80 & 97.72 \\
\hline $50 \%$ R.D & 17.06 & 1.88 & 97.07 & 17.91 & 1.95 & 102.31 \\
\hline $50 \% R . D+F$ & 18.55 & 2.14 & 105.96 & 19.42 & 2.20 & 110.81 \\
\hline $50 \%$ R.D + T & 19.12 & 2.24 & 107.40 & 20.11 & 2.30 & 114.57 \\
\hline $50 \%$ R.D + P & 19.61 & 2.32 & 110.39 & 20.53 & 2.38 & 117.13 \\
\hline $100 \%$ R.D & 18.13 & 2.43 & 101.85 & 19.14 & 2.50 & 109.15 \\
\hline $100 \%$ R.D + F & 21.01 & 2.62 & 116.72 & 22.04 & 2.70 & 125.69 \\
\hline $100 \%$ R.D + T & 21.95 & 2.81 & 120.23 & 23.04 & 2.89 & 131.22 \\
\hline $100 \%$ R.D + P & 22.47 & 2.89 & 126.06 & 23.64 & 2.97 & 134.68 \\
\hline L.S.D (0.05) & 0.14 & 0.04 & 5.20 & 0.06 & 0.03 & 8.80 \\
\hline
\end{tabular}

R.D: Recommended dose.

$\mathrm{T}$ : Tomato compost extract.

F: Fruit leaves compost extract.

P: Potato compost extract.

\section{2- $\mathrm{N}, \mathrm{P}, \mathrm{K}$ and Fe $\mathrm{mg} / \mathbf{1 0 0 g m}$ (on dry weight basis):}

The statistical analysis of the data presented in Table (4) indicate the effect of $\mathrm{N}+\mathrm{P}+\mathrm{K}$ fertilization at the rates of $0,50 \%$ and $100 \%$ from the recommended dose (for spinach plant), foliar application of potato, tomato and fruit leaves extracts as well as their interaction on the contents of $N, P$ \& $\mathrm{K} \%$ and $\mathrm{Fe}(\mathrm{mg} / 100 \mathrm{~g} \mathrm{DW})$ in spinach plant. 
Data at Table (4) reveal that the mean values of $\mathrm{N}, \mathrm{P}, \mathrm{K}$ and $\mathrm{Fe}$ contents significantly increased due to $\mathrm{N}+\mathrm{P}+\mathrm{K}$ fertilization, foliar of residual plant extracts and their interaction as compared to the control treatment during both seasons of this investigation.

Concerning the effect of potato, tomato and fruit leaves extracts, data at the same Table show that, foliar spraying of residual potato extracts in a single form increased the mean values percentage of $\mathrm{N}, \mathrm{P}, \mathrm{K} \%$ and $\mathrm{Fe}$ $\mathrm{mg} / 100 \mathrm{~g}$, respectively by $20,17,18$ and $31 \%$ in the $1^{\text {st }}$ season and $30,12,19$ and $37 \%$ in the $2^{\text {nd }}$ season over the untreated plants.

As for the mean values of $\mathrm{N}, \mathrm{P}, \mathrm{K} \%$ and $\mathrm{Fe}(\mathrm{mg} / 100 \mathrm{~g})$ in spinach plant foliage as affected by soil addition of $\mathrm{N}+\mathrm{P}+\mathrm{K}$ at the rates of this study, data in Table (4) reflected that the mean values of these parameters were increased as the level of recommended doses were increased from 50 to 100 $\%$ except for $\mathrm{Fe}$ content whereas, these increases did not reach to the level of significant. For all parameters; the highest values were realized for the treatment of $100 \% \mathrm{~N}, \mathrm{P}, \mathrm{K}$ and recorded $3.26,0.551,4.18 \%$ and 49.36 $\mathrm{mg} / 100 \mathrm{~g}$ in the $1^{\text {st }}$ season and $3.55,0.532,4.37 \%$ and $47.61 \mathrm{mg} / 100 \mathrm{~g}$ in the $2^{\text {nd }}$ season for the parameters of $\mathrm{N}, \mathrm{P}, \mathrm{K} \%$ and Fe $\mathrm{mg} / 100 \mathrm{~g}$, respectively

Regarding the effect of interaction; data at the same Table also reveal that soil addition of $\mathrm{N}, \mathrm{P}$ and $\mathrm{K}$ fertilizers for spinach plant at any level of this investigation coupled with spraying the extracts of potato or tomato or fruit leaves residuals led to increasing the mean values of $\mathrm{N}, \mathrm{P}, \mathrm{K} \%$ and $\mathrm{Fe}$ $(\mathrm{mg} / 100 \mathrm{~g})$ than those obtained for the plants received $\mathrm{N}, \mathrm{P}$ and $\mathrm{K}$ fertilizers only. In this respect; using of potato extract at any level of mineral fertilization was superior for increasing the mean values of these parameters. This trend was true during both seasons.

From the results mentioned previously it can be noticed that increasing the rate of $\mathrm{N}+\mathrm{P}+\mathrm{K}$ fertilization from 50 to $100 \% \mathrm{RD}$ significantly increased the mean values of $\mathrm{N}, \mathrm{P}$ and $\mathrm{K}$ contents of the leaves of spinach plant; such effect was insignificant on the values of $\mathrm{Fe}(\mathrm{mg} / 100 \mathrm{~g})$. This can be attributed to the depression effect for the highest levels of $N$ and $P$ fertilization on Fe absorption by the plant. On the other hand, foliar spraying of the plant residual extracts has been corrected this trend and increased the mean values of all parameters as a result of its content from available macro and micro nutrients.

These findings were confirmed with those obtained by Abdel-Razik (1996); Gawish (1997); El-Talawy (1998); Mordogan (2000); Raikova (2000); Paradiso et al.,(2001); Tomar(2001); Ramadan(2004); Gulser(2005); Lashin(2006); Rashwan (2006) And Abd-Allah (2001) who stated that; raising the level of $\mathrm{N}$ - added from 45 to $60 \mathrm{Kg} / \mathrm{fad}$ resulted in significant increase in Fe-content in spinach leaves. Increase of $\mathrm{N}$-added up to 75 $\mathrm{Kg} / \mathrm{fad}$ significantly decreased Fe-content. Foliar spraying coupled with $\mathrm{N}$ Fertilization significantly increased Fe-content in spinach leaves at any level of $\mathrm{N}$-addition. 
Table (4): N, P, K and Fe concentrations (on dry weight basis) in spinach plant as affected by mineral fertilization and some residual plant extracts.

\begin{tabular}{|c|c|c|c|c|c|c|c|c|}
\hline Seasons & \multicolumn{4}{|c|}{ 2006-2007 } & \multicolumn{4}{|c|}{ 2007-2008 } \\
\hline Treatments & $\mathrm{N} \%$ & P\% & $\mathbf{K} \%$ & $\begin{array}{c}\mathrm{Fe} \\
(\mathrm{mg} / 100 \mathrm{~g})\end{array}$ & N\% & P\% & $\mathrm{K} \%$ & $\begin{array}{c}\mathrm{Fe} \\
(\mathrm{mg} / 100 \mathrm{~g})\end{array}$ \\
\hline Control & 2.27 & 0.411 & 3.22 & 37.00 & 2.36 & 0.428 & 3.37 & 35.07 \\
\hline $\mathbf{F}$ & 2.63 & 0.459 & 3.73 & 47.66 & 2.92 & 0.452 & 3.93 & 46.14 \\
\hline $\mathbf{T}$ & 2.69 & 0.472 & 3.80 & 48.03 & 3.02 & 0.464 & 3.97 & 47.75 \\
\hline $\mathbf{P}$ & 2.73 & 0.482 & 3.81 & 48.33 & 3.06 & 0.473 & 4.02 & 47.92 \\
\hline 50\% R.D & 2.89 & 0.502 & 3.92 & 48.03 & 3.13 & 0.471 & 4.11 & 46.29 \\
\hline $50 \% R . D+F$ & 3.10 & 0.523 & 4.09 & 48.63 & 3.33 & 0.501 & 4.26 & 47.72 \\
\hline $50 \%$ R.D + T & 3.18 & 0.532 & 4.12 & 50.33 & 3.45 & 0.513 & 4.31 & 49.25 \\
\hline $50 \%$ R.D + P & 3.21 & 0.544 & 4.13 & 51.36 & 3.49 & 0.522 & 4.33 & 49.99 \\
\hline 100\% R.D & 3.26 & 0.551 & 4.18 & 49.36 & 3.55 & 0.512 & 4.37 & 47.61 \\
\hline $100 \%$ R.D + F & 3.40 & 0.562 & 4.27 & 51.30 & 3.64 & 0.532 & 4.51 & 49.59 \\
\hline $100 \%$ R.D + T & 3.51 & 0.573 & 4.38 & 52.26 & 3.76 & 0.553 & 4.62 & 50.26 \\
\hline $100 \%$ R.D + P & 3.58 & 0.574 & 4.44 & 53.23 & 3.88 & 0.562 & 4.66 & 51.12 \\
\hline L.S.D (0.05) & 0.04 & 0.05 & 0.13 & 2.64 & 0.03 & 0.02 & 0.03 & 1.04 \\
\hline
\end{tabular}

R.D: Recommended dose.

T: Tomato compost extract.
F: Fruit leaves compost extract.

P: Potato compost extract.

\section{3- $\mathrm{NO}_{3}-\mathrm{N}$ and $\mathrm{NO}_{2}-\mathrm{N}$ content in spinach plant:}

Data illustrated in Table (5) show the effect of $\mathrm{N}+\mathrm{P}+\mathrm{K}$ fertilization levels, foliar spraying of plant residual extracts and their interactions on nitrate and nitrite contents on fresh weight basis of spinach plant at marketing stage.

Concerning with the effect of plant residual extracts in foliar way, data reveal that nitrate and nitrite contents were significantly increased due to spraying any of residual plant extracts during both seasons of the experiments. In the $1^{\text {st }}$ season; the highest values (234 and $\left.2.63 \mathrm{ppm}\right)$ for $\mathrm{NO}_{3}-\mathrm{N}$ and $\mathrm{NO}_{2}-\mathrm{N}$, respectively were realized for the plants treated with tomato foliage residual extract, while the lowest one (192 and $2.12 \mathrm{ppm}$ ) were obtained for the untreated plants. The same trend was happened during the $2^{\text {nd }}$ season.

Regarding the effect of mineral fertilization data at the same Table reflected that, soil addition of $\mathrm{N}+\mathrm{P}+\mathrm{K}$ fertilizers either at the rate of $50 \%$ or $100 \%$ from the recommended doses for spinach plant sharply and significantly increased $\mathrm{NO}_{3}-\mathrm{N}$ and $\mathrm{NO}_{2}-\mathrm{N}$ contents in spinach plant. Comparing with the control treatment; soil addition of $\mathrm{N}+\mathrm{P}+\mathrm{K}$ fertilizers at the rate of $50 \%$ from (RD) led to increase the mean values of $\mathrm{NO}_{3}-\mathrm{N}$ and $\mathrm{NO}_{2}-\mathrm{N}$, respectively by 89 and $78 \%$ in the $1^{\text {st }}$ season and 92 and $84 \%$ in the $2^{\text {nd }}$ season. Further addition of N, P and K fertilizers at the rate of $100 \%$ increased the values of $\mathrm{NO}_{3}-\mathrm{N}$ and $\mathrm{NO}_{2}-\mathrm{N}$ by 200 and $121 \%$ in the $1^{\text {st }}$ season and 200 and $120 \%$ in the $2^{\text {nd }}$ season over the control treatment.

With the regard to the effect of interaction between the treatments of this investigation; data in Table (5) indicate that, spraying any residual plant extracts on the leaves of spinach plant grown under the rates of $\mathrm{N}+\mathrm{P}+\mathrm{K}$ fertilization 50 or $100 \%$ from the recommended doses highly decreased the 
mean values of $\mathrm{NO}_{3}-\mathrm{N}$ and $\mathrm{NO}_{2}-\mathrm{N}$ (ppm) than those obtained for the plants treated with the same rates of $\mathrm{N}+\mathrm{P}+\mathrm{K}$ only. In this connection; the highest decrease percentages which calculated to be 67 and $60 \%$ in the $1^{\text {st }}$ season and 67 and $39 \%$ in the $2^{\text {nd }}$ season for the contents of $\mathrm{NO}_{3}-\mathrm{N}$ and $\mathrm{NO}_{2}-\mathrm{N}$, respectively were realized for the plants treated with $100 \%$ from the (RD) of $\mathrm{N}, \mathrm{P}$ and $\mathrm{K}$ coupled with spraying with potato foliage extract less than the same values for the plants received $100 \%$ RD only.

It could be concluded that, the accumulation of nitrate and nitrite in spinach fresh leaves increased as the level of mineral fertilizers increased. This effect is a natural phenomenon that occurs when the uptake of $\mathrm{NO}_{3}$ - by the roots exceeds its reduction and subsequent assimilation within the plant, so the unutilized $\mathrm{NO}_{3}{ }^{-}$will be stored in plant tissues. Foliar spraying of residual plant extracts, which contain micronutrients, in the presence of mineral fertilizers resulted in pronounce decrease in the values of $\mathrm{NO}_{3}-\mathrm{N}$ and $\mathrm{NO}_{2}-\mathrm{N}$ in spinach plant due to the role played by micronutrients for increasing the activity of nitrate reductase enzymes.

These results are in the harmony with the conclusions reported by Malakouti, et al., (1999), Ai, et al., (2000), Abdel-Rahman et al., (2001), ElAgrodi et al., (2001), Ramadan (2004), Lashin (2006), Rashwan (2006) and Abd-Allah (2001) who stated that; increasing the rate of $\mathrm{N}$-fertilization gradually and significantly increased $\mathrm{NO}_{3}-\mathrm{N}$ and $\mathrm{NO}_{2}-\mathrm{N}$ content in spinach plant. Foliar application of $(\mathrm{Fe}+\mathrm{Mo})$ at any level of $\mathrm{N}$-fertilization sharply and high significantly decreased the values of nitrate and nitrite contents than those obtained when the same $\mathrm{N}$ - rates were added only.

Table (5): Nitrate \& nitrite content of spinach plant as affected by mineral fertilization and some residual plant extracts.

\begin{tabular}{|c|c|c|c|c|}
\hline Seasons & \multicolumn{2}{|c|}{ 2006-2007 } & \multicolumn{2}{|c|}{ 2007-2008 } \\
\hline $\begin{array}{l}\text { character } \\
\text { Treatments }\end{array}$ & $\mathrm{NO}_{3}-\mathrm{N}$ ppm & $\mathrm{NO}_{2}-\mathrm{N}$ ppm & $\mathrm{NO}_{3}-\mathrm{N}$ ppm & $\mathrm{NO}_{2}-\mathrm{N}$ ppm \\
\hline Control & 192 & 2.12 & 201 & 2.22 \\
\hline$F$ & 214 & 2.25 & 225 & 2.33 \\
\hline $\mathbf{T}$ & 234 & 2.63 & 242 & 2.76 \\
\hline $\mathbf{P}$ & 221 & 2.43 & 231 & 2.48 \\
\hline $50 \%$ R.D & 363 & 3.93 & 385 & 4.09 \\
\hline $50 \% R . D+F$ & 315 & 3.05 & 328 & 3.21 \\
\hline $50 \%$ R.D + T & 304 & 2.94 & 318 & 3.38 \\
\hline $50 \%$ R.D + P & 265 & 2.66 & 304 & 3.10 \\
\hline 100\% R.D & 581 & 4.74 & 596 & 4.91 \\
\hline 100\% R.D + F & 416 & 3.98 & 423 & 4.12 \\
\hline 100\% R.D + T & 372 & 3.13 & 388 & 3.88 \\
\hline 100\% R.D + P & 347 & 2.97 & 356 & 3.52 \\
\hline L.S.D (0.05) & 8.76 & 0.33 & 9.26 & 0.52 \\
\hline $\begin{array}{l}\text { D: Recommended } \\
\text { Tomato compost }\end{array}$ & e. & $\begin{array}{l}\text { Fruit les } \\
\text { Potato }\end{array}$ & $\begin{array}{l}\text { post extract. } \\
\text { extract. }\end{array}$ & \\
\hline
\end{tabular}

4- Total and soluble oxalate contents $(\mathrm{g} / \mathbf{1 0 0 g})$ on dry weight bases:

An accumulation of total and soluble oxalate in spinach leaves as affected by foliar application of plant residual extracts, soil fertilization of mineral fertilizers and their interactions are presented at Table (6). 
Data indicate that ; foliar spraying of plant residual extracts as solely had no significant effect on the mean values of total oxalate, while such effect significantly increased the values of soluble oxalate as compared to the untreated plants. The highest values of soluble oxalate (3.09 and 3.17 $\mathrm{g} / 100 \mathrm{~g}$ ) were recorded for the plants treated with tomato extract, while the lowest one $(2.87$ and $2.96 \mathrm{~g} / 100 \mathrm{~g})$ were realized for the untreated plant in the $1^{\text {st }}$ and $2^{\text {nd }}$ seasons, respectively.

Referring to the effect of mineral fertilization, data at the same Table show that; soil addition of $\mathrm{N}+\mathrm{P}+\mathrm{K}$ fertilizers at any rate studied significantly increased the average mean values of total and soluble oxalate $(g / 100 \mathrm{~g} D W)$ in the leaves of spinach plant comparing with the control treatment. In addition, increasing the rate of $\mathrm{N}, \mathrm{P}$ and $\mathrm{K}$ fertilization from 50 to $100 \%$ from the $(\mathrm{RD})$ for spinach plant had no significant effect on the values of total oxalate; such effect significantly increased the mean values of soluble oxalate. This trend was true during both seasons.

With respect to the effect of interaction between the studied treatments, data at Table (6) indicate that; there is no significant differences between the average values of total oxalate in spinach plant due to an addition of $\mathrm{N}+\mathrm{P}+\mathrm{K}$ fertilizers combined with spraying of residual plant extracts as compared to the same values obtained for the plants treated with $\mathrm{N}+\mathrm{P}+\mathrm{K}$ fertilizer only. On the other hand, spraying of residual plant extracts under any level of $\mathrm{N}+\mathrm{P}+\mathrm{K}$ fertilization significantly decreased the mean values of soluble oxalate than those obtained for the plants received $\mathrm{N}, \mathrm{P}$ and $\mathrm{K}$ fertilizers solely. The lowest values of soluble oxalate $(3.23$ and $3.36 \mathrm{~g} / 100 \mathrm{~g}$ DW) in the $1^{\text {st }}$ and $2^{\text {nd }}$ seasons, respectively were realized for the plants treated with $50 \%$ from $\mathrm{RD}$ of $\mathrm{N}+\mathrm{P}+\mathrm{K}$ coupled with spraying with potato foliage extract.

Obtained data illustrate that nitrate reduction always occurs in parallel with oxalate synthesis in the leaves of spinach plant so there is a relationship between the concentration of oxalate and nitrate accumulation. This relationship suggests the possibility that most $\mathrm{OH}$ ions generated during nitrate reduction might be neutralized by oxalate that is produced concomitantly in spinach leaves.

These is tight coupling exists between $\mathrm{NO} 3$ reduction and oxalate syntheses in spinach leave. The obtained results were in agreement with those investigated by Sugiyama and Hirooka (1992) showed that oxalate is a major organic acid in spinach leaves and that a close relationship exists between the concentrations of oxalate and reduced nitrogen in leaves when various cultivars of spinach were grown hydroponically with nitrate as the nitrogen source.

These results were in agreement with Yalcin and Topcuoglu (1994), Takebe et al., (1995), Siomos and Dogras (1999), Abdel-Rahman et al., (2001), El-Agrodi et al., (2001), Ramadan (2004). 
Table (6): Total \& soluble oxalate concentration (g/100g D.W) on spinach plant as affected by mineral fertilization and some residual plant extracts.

\begin{tabular}{|c|c|c|c|c|}
\hline Seasons & \multicolumn{2}{|c|}{ 2006-2007 } & \multicolumn{2}{c|}{ 2007-2008 } \\
\hline character & \multirow{2}{*}{ T. Oxalate } & S. Oxalate & T. Oxalate & S. Oxalate \\
\hline Treatments & 4.55 & 2.87 & 4.63 & 2.96 \\
\hline Control & 4.67 & 2.95 & 4.77 & 3.05 \\
\hline F & 4.88 & 3.09 & 4.96 & 3.17 \\
\hline T & 4.75 & 3.02 & 4.83 & 3.15 \\
\hline P & 5.82 & 3.55 & 5.95 & 3.67 \\
\hline 50\% R.D & 5.74 & 3.47 & 5.82 & 3.55 \\
\hline 50\%R.D + F & 5.43 & 3.29 & 5.63 & 3.43 \\
\hline 50\% R.D + T & 5.34 & 3.23 & 5.52 & 3.36 \\
\hline 100\% + R.D & 6.44 & 3.94 & 6.62 & 3.84 \\
\hline 100\% R.D + F & 5.87 & 3.59 & 6.24 & 3.67 \\
\hline 100\% R.D + T & 5.79 & 3.41 & 6.13 & 3.62 \\
\hline 100\% R.D + P & 5.63 & 3.34 & 5.95 & 3.55 \\
\hline L.S.D (0.05) & 0.88 & 0.06 & 0.63 & 0.03 \\
\hline R.D: Recommended dos & F. Fruit leaves compost extract.
\end{tabular}

R.D: Recommended dose.

T: Tomato compost extract.

F: Fruit leaves compost extract.

Conclusion: Under the same condition of this investigation it can be recommended that; soil addition of $\mathrm{N}+\mathrm{P}+\mathrm{K}$ fertilizers at the rate of $50 \%$ from the recommended doses for spinach plant coupled with foliar spraying of potato foliage residual extract is recommended as the best treatment for producing a safe yield of spinach plant. Meanwhile, the highest yield was obtained from the $\mathrm{N}, \mathrm{P}$ and $\mathrm{K}$ recommended doses and spraying the residual extract, especially the one extracted from potatoes plant.

\section{REFERENC}

Abd Allah, G. E. A. (2001). Effect of heavy nitrogen application on yield chemical composition of some vegetable crops. Ph. D. Thesis. Fac. Agric. Mansoura Univ., Egypt.

Abd El-Hamid, M. T.; T. Horiuchi and S. Oba (2004). Composting of rice straw with oil seed rape cake and poultry manure and its effects on soil properties. Bioresource Technology. 93: 183-189.

Abd El-Wahab, A. F. M. ; F. SH. F. Badawi. ; G. A. A. Mekhemar and W. M. El-Farghal (2007). Effect of enriched compost tea and Rhizobacteria on Nodulation, growth and yield of chick pea in sandy soil. Minufiya $\mathrm{J}$ .Agric. Res. 32 (1): 297-321.

Abdel-Rahman, M. M., R. A. El-Shabraway, M. E. Abou-El-Nasr and M. A. ElSaei. (2001). Response of two spinach cvs (Spinach oleracea L.) to different $\mathrm{N}$-source and levels in fertilization to vegetative growth, yield, chemical composition, nitrate and oxalate. J. Agric. Sci. Mansoura Univ. 26(4): 2235-2262. 
Abdel-Razik, A. H. (1996). Influence of nitrogen and gibberellic acid on growth, yield and chemical composition of spinach. J. Agric. Sci. Mansoura Univ. 21 (1): 343:349.

Abo El-Fadl, M. (1970). Organic fertilizers. Dar-Elbian- Cairo.

Ai, S. Y.; S. H. Tang; S. X. Li and C. Y. Chi. (2000). Influence of nitrogen rates on nitrate accumulation and distribution in vegetables. J. South China Agric. Univ., 21 (2): 14-17.

Amer, M. M. A. (2005). Effect of N, K level and timing of application on some yield components of wheat varieties in the North Middle Delta region. M. Sc. Thesis. Fac. Of Agric., Tanta Univ.

Baker. C. J. L. (1954). The determination of oxalates in fresh plant materials. Analyst. 77:340-344.

Bohn, T., L. Davidsson, T. Walczyk, and R. F.Hurrell. (2004). Fractional magnesium absorption is significantly lower in human subjects from a meal served with an oxalate-rich vegetable, spinach, as compared with a meal served with kale, a vegetable with a low oxalate content . British nutrition 91; 601-606.

Chapman, H. D.; F. Paker and Pratt (1961). Methods of Soil Analysis. Part 2, A. S. A Madison. Wisconsin.

El-Agrodi, M. W.; Z. M. El-Sirafi; A. A. Rezk and G. A. A. Baddour. (2001). Nitrate accumulation as affected by nitrogen fertilization levels and $(\mathrm{Fe}$ - Mo) foliar application on spinach plant at marketing stage. J. Agric Sci. Mansoura Univ., 26 (12):8247-8261.

Elia, A.; P. Santamaria, and F. Serio. (1998). Nitrogen nutrition, yield and quality of spinach. The Science of food and Agric. 76: 341-346.

El-Sirafy, Z. M. ;G.A. Baddour and Kholod A. El-Nakma (2008). Substitution of compost tea instead of apart of mineral fertilizers for pea plant (Pisum sativum L.) .J. Agric. Sci. Mansoura Univ., 33(8):6279-6289.

El-Talawy, M. M. (1998). Effect of nitrogen and some micronutrient application on spinach (Spinacia oleracea L.) M.Sc. Thesis, Fac. Agric. Moshtohor, Zagazig Univ.

Franceschi, V. R. and F.A. Loewus. (1995). Oxalate biosynthesis and function in plants and fungi. In Calcium Oxalate In Biological Systems, ed. S. R. Khan. 113-130. Boca Ration, Florida: CRC Press.

Gangolli, S.D. ; Van Den Brandt, P.A.; Feron, V.J.; JanZowsky, C.; and Winshnok, J.S. (1994). Nitrate, nitrite and N-nitroso compounds. Eur $j$ Pharmacol, Environ Toxicol Pharmacol Sect. 292; 1-38.

Gawish, A. R. (1997). Trails to reduce nitrate and oxalate contents in some leafy vegetables. 1 - Interactive effect of different nitrogen fertilization regimes and nitrification inhibitor on growth and yield of both spinach and lettuce. Zagazig J. Agric. Res. 24 (1).

Gomez, K. A. and A. A. Gomez (1984). Statistical Procedures for Agricultural Research. $2^{\text {nd }}$ Ed. John Widy and Sons pp. 680.

Gulser, F. (2005). Effect of ammonium sulphate and urea on NO3- and NO2accumulation, nutrient contents and yield criteria in spinach. ScientiaHorticulturae. 106(3): 330-340.

Herondel, J. I. and J. L. Herondel (2001). Nitrate and man, Toxic, Harmless or beneficial. Centre Haspitalier Universitaire de caen, France. 
Hesse, P. R. (1971). A Text Book of Soil Chemical Analysis . John Murry (publishers) Ltd, 50 Albermarle Street, London.

Ingham, E. R. (2000a). Brewing compost tea. Kitchen gardener, Oct., Nov:1619.

Ingham, E. R. (2000b). The compost tea brewing manual. Unison communication, corvallis, Oregon.

Jackson, M. L. (1967). Soil Chemical Analysis. Printic Hall of India, New Delhi..

Jaworska, G. (2005). Content of nitrates, nitrites, and oxalates in New Zealand spinach. Food Chemistry, 89,235-242.

Kawazu, Y., M. Okimura, Y. Ishii, and SD. Yui. (2003). Varietal and seasonal differences in oxalate content of spinach. Scientia Horticulturae 97:203210.

Lashin, Z. A. Z. (2006). Changes of some nutrients under polluted factors. M. Sc. Thesis. Fac. Agric. Mansoura Univ., Egypt.

Lewandowski, S., and A.L.Rodgers. (2004).Idiopathic calcium oxalate urolithiasis: risk factors and conservative treatment. Clinica chimica acta. 345: 17-34.

Libert, B, and V. R. Feranceschi. (1987). Oxalate in crop plants. Agric. and Food Chem. 35:926-938.

Maftoun, M.; F. Moshiri; N. Karimian and A. M. Ronaghi (2004). Effects of two organic wastes in combination with phosphorus on growth and chemical composition of spinach and soil properties. J. Plant Nutri. 27 (9): 1635-1651.

Malakouti, M. J.; M. Navabzadeh and S. H. R. Hashemi (1999). The effect of different amounts of $\mathrm{N}$-fertilizers on the nitrate accumulation in the edible parts of vegetables. Improved-crop-quality-by-nutrientmanagement. 43-45.

Mordogan, N. (2000). Effect of different nitrogen sources and levels on nitrogen compounds in spinach. Ege Univsitiesi Ziraat Fatultesi Dergisi. 37 (1): 121-127.

Noonan, S. C., and G.P. Savage. (1999). Oxalate content of foods and its effect on humans. Asia Pacific J.Clinical Nutri 8 (1): 64-74.

Ogawa, Y., T.Miyazato, and T.Hatano. (2000). Oxalate and urinary stones. World J. Surgery 24:1154-1159.

Paradiso, R.; S. de Pascale; G. Barbieri and S. de Pascale (2001). Effects of water regime and nitrogen supply on water use, yield and nitrate content of spinach. Italus Hortus. 8 (4): 14-21.

Piper, C. S. (1950). Soil and Plant Analysis. Inter Science Publisher Inc. New York.

Proietti, S., S. Moscatello, A.Leccese, G.Golla, and A. Battistelli. (2004).The effect of growing spinach (spinacia oleracec L.) at two light intensities on the amount of oxalate, ascorbate and nitrate in their leaves. J. Horti. sci. and Biotechn. 79(4):606-609.

Raikova, L. (2000). Effect of nitrogen and potassium fertilizer forms on the productivity and nitrate accumulation in spinach. Pochvojnanie Agrokhimiya I Ekologiya. 35 (1): 24-28. 
Ramadan, A. Y. (2004). Effect of planting date and slow release nitrogen fertilizers on yield and quality of spinach (Spinacia oleracea L.). Ph. D. Thesis. Fac. Agric., Mansoura Univ., Egypt.

Rashwan, E. M. (2006). Study of soil fertility under pollution factors. M. Sc. Thesis. Fac. Agric. Mansoura Univ., Egypt.

Ryan, M.; D. Wilson.; P. Hepperly.; J. Travis.; N Halbrendt and A. Wise (2005). Compost tea potential is still brewing. Biocycle .46(6): 30-32.

Schmitz, J (2002). Compost teas work on center pivot farm. Capitol press. Nov. 29: $\mathrm{p} 20$.

Singh, J.P. (1988). A rapid method for determination of nitrate in soil and plant extracts. Plant and Soil. 110:137-139.

Siomos, A.S.; and Dogras, C.C. (1999). Nitrates in vegetables produced in Greece. Journal of vegetable crop production, 5 (2), 3-13.

Sugiyama, N. and M. Hirooka. (1992). Relationship between oxalate and reduced $\mathrm{N}$ concentrations in spinach leaves (in Japanese with English summary). J. Japan. Soc. Hort. Sci. 61, 569-574.

Takebe, M., T. Ishihara, K. Matsuno, J. Fujimoto and T. Yoneyama (1995). Effect of nitrogen application on the contents of sugars, ascorbic acid, nitrate and oxalic acid in spinach (Spinacia oleracea L) and komatsuna (Brassica compestris L.). Japanese J. Soil Sci., Plant Nutr., 66: 238246.

Tartoura E. A. A.; M. A. El-Saei and A. F. Abdel Wahab (2005). Organic farming using a compost tea made from rice straw. Egypt. J. Appl. Sci., $20(10 \mathrm{~A}): 232-249$.

Tomar, K. S. (2001). Effect of phosphorus, magnesium levels and cutting on the yield and chemical composition of spinach. Advances in Plant Sci. 14 (2): $471-474$.

Yalcin, S. R.and B. Topcuoglu. (1994). Effects of nitrogen and phosphorus on accumulation of oxalic acid and nitrate and some nutrient contents in chard. An Kara Universitesi Ziraat Fakultesi Yilligi, $44(1,2):$ 217-228.

Zhang, Y. P., X. J. Xu, X. Y. Lin, Y. S. Zhang, L. S. Zhang, and T. T. Chen. (2004). Influence of different nitrogen levels on biomass, nitrate and oxalate accumulation in spinach (in Chinese with English abstract). Plant Nutri. and Fertilizer Sci. 5:494-498. 
El-Sirafy, Z. M. et al.

التركيب الكيمساوى والجـوده لتبـات السبانخ تحت تـاثير استخدام التسـميد المعدنى وبعض المستخلصات النباتيه.

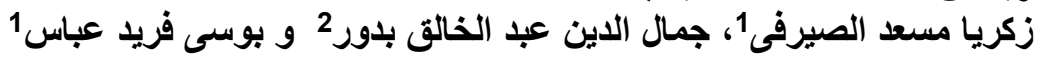

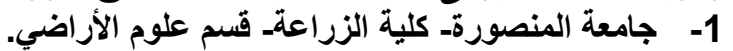

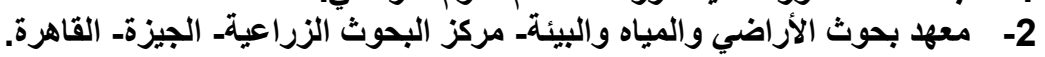

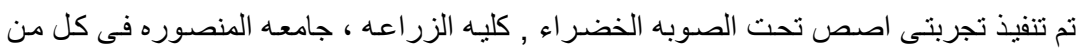

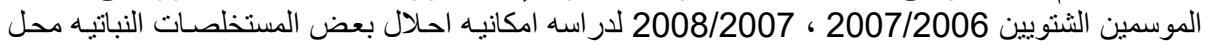
جزء من الاسمده المعدنيه لانتاج محصول المع آمن للاستخدام من السبانخ.

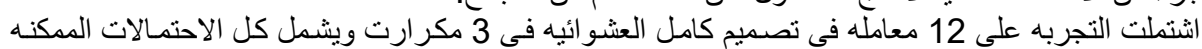

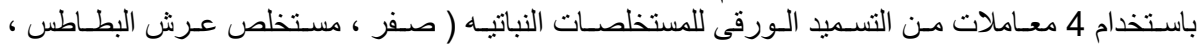

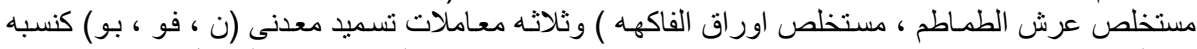

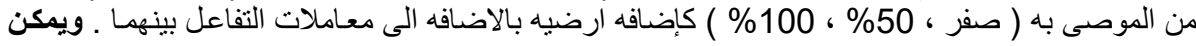
تلخيص النتائج المتحصل عليه عليها على النحو التالى :

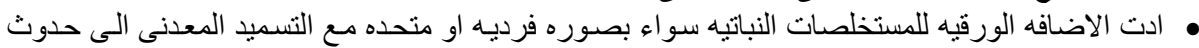

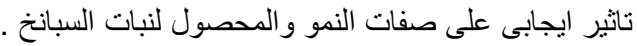

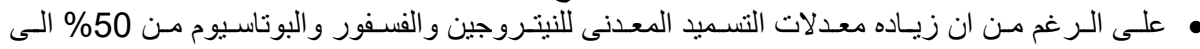

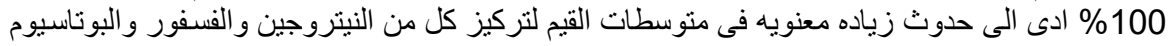

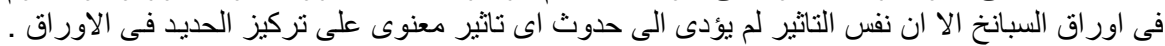

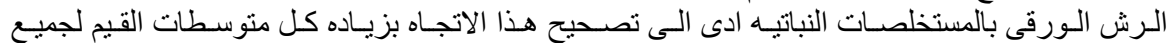
العناصر .

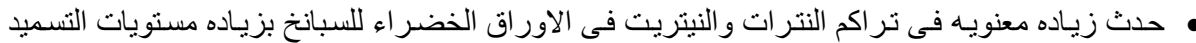

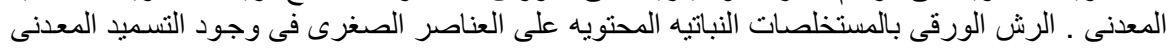

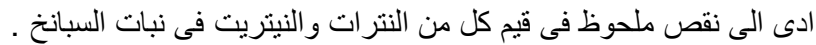

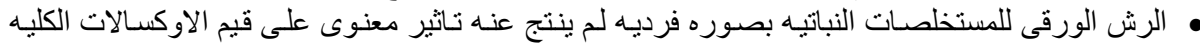

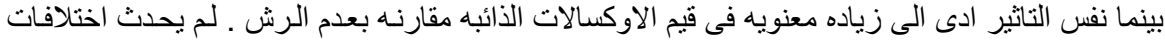

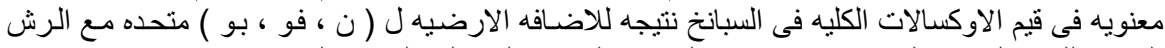

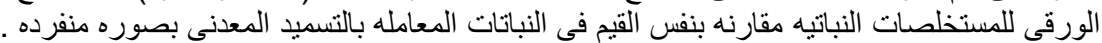

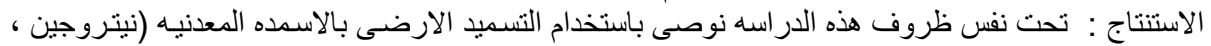

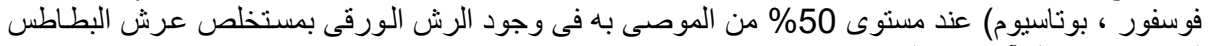
لتحقيق محصول آمن من السبانخ. 
J. Agric. Sci. Mansoura Univ., 33 (12): 9155 - 9170, 2008

Table (1): Some physico-chemical properties of soil used in the two seasons:

\begin{tabular}{|c|c|c|c|c|c|c|c|c|c|c|c|c|c|c|c|c|}
\hline \multirow[b]{2}{*}{ seasons } & \multicolumn{4}{|c|}{ Mechanical analysis } & \multirow[b]{2}{*}{ T. class } & \multirow{2}{*}{$\begin{array}{l}\text { EC dS } \mathrm{m}^{-1} \\
\text { soil paste } \\
\text { extract }\end{array}$} & \multirow{2}{*}{$\begin{array}{c}\mathrm{PH}^{\mathrm{H}} 1: 2.5 \\
\text { suspensi } \\
\text { on }\end{array}$} & \multirow{2}{*}{$\begin{array}{c}\mathrm{CaCO}_{3} \\
\%\end{array}$} & \multirow{2}{*}{$\begin{array}{l}\text { OM } \\
\%\end{array}$} & \multirow{2}{*}{$\begin{array}{c}\text { S.P } \\
\%\end{array}$} & \multicolumn{6}{|c|}{ Available nutrients ppm } \\
\hline & $\begin{array}{c}\text { C.sand } \\
\%\end{array}$ & $\begin{array}{l}\text { f.sand } \\
\%\end{array}$ & Silt & clay\% & & & & & & & $\mathbf{N}$ & $\mathbf{P}$ & $\mathrm{K}$ & $\mathrm{Fe}$ & $\mathbf{M n}$ & $\mathrm{Zn}$ \\
\hline $1^{\text {st }}$ & 2.3 & 19.5 & 28.6 & 49.6 & Clay & 2.78 & 7.9 & 1.95 & 2.08 & 61 & 38 & 2.6 & 295 & 16.8 & 9.7 & 1.9 \\
\hline $2^{\text {nd }}$ & 2.8 & 16.2 & 27.9 & 53.1 & Clay & 3.02 & 8.0 & 1.86 & 1.97 & 65 & 43 & 3.1 & 305 & 17.3 & 11.2 & 1.7 \\
\hline
\end{tabular}

